DOI: $10.34015 / 2523-4552.2020 .2 .11$

УДК 343.827

Степанюк A. X.,

доктор юридичних наук, професор, завідувач відділу дослідження проблем кримінального та кримінальновиконавчого права Науково-дослідного інституту вивчення проблем злочинності імені академіка В. В. Сташиса НАПрН України ORCID: 0000-0002-0877-6319

\title{
РЕЖИМ - ЦЕ НЕ «ПОРЯДОК ВИКОНАННЯ І ВІДБУВАННЯ ПОКАРАННЯ», А ПРОГРАМА СОЦІАЛЬНОЇ ДОПОМОГИ ПРИ ПОВОДЖЕННІ $З$ УВ'ЯЗНЕНИМИ
}

У кримінально-виконавчому праві України усталеною $є$ думка, що режим у виправних і виховних колоніях - це є порядок виконання і відбування покарання. Таке розуміння режиму має свої історичні корені у радянському гулагівському минулому. Саме з 30 -х років минулого сторіччя за наказами й інструкціями НКВС режим для засуджених став втіленням порядку виконання і відбування позбавлення волі на підставі їх ізоляції. 3 того часу і по сьогоднішній день забезпечення ізоляції засуджених розглядається як основна вимога режиму. У радянському виправно-трудовому праві виходили з того, що ізоляція уособлює в собі обмеження прав і свобод притаманних позбавленню волі, тобто кару. Режим вимагає здійснювати нагляд за позбавленими волі шляхом цілодобового і постійного контролю в місцях їх проживання і праці. Засобами забезпечення режиму $є$ обшуки засуджених та приміщень, в яких вони знаходяться, огляд території колонії; застосування до позбавлених волі заходів фізичного впливу, спеціальних засобів і зброї. На відміну від такого розуміння режиму, Європейські тюремні правила (ЄТП) розрізняють ув'язнення і позбавлення волі і виходять 3 того, що ув'язнення і позбавлення волі $\epsilon$ покаранням вже самі по собі і тому режим для засуджених ув'язнених не повинен збільшувати страждання, заподіяні ув'язненням. Режим за ЄТП складається зі збалансованої програми консультацій, піклування, турботи і допомоги, спрямованої на полегшення реінтеграції ув'язнених у вільне суспільство після закінчення їхнього строку ув'язнення. Режим передбачає надання можливості отримання освіти, професійної підготовки , заняття спортом, організації відпочинку. ЄТП далекі від того, щоб розглядати режим як порядок виконання і відбування покарання. За ЄТП режим є правилами поводження з ув'язненими, саме так має тлумачитися режим і у кримінально-виконавчому праві України. Актуальність дослідження даного аспекту режиму зумовлена необхідністю розробки пропозицій у галузі кримінально-виконавчого права, які б відповідали законодавству Європейського Союзу, що передбачено Концепцією реформування (розвитку) пенітенціарної системи України. 
Ключові слова: режим; порядок; виконання покарань; ізоляція; правила поводження.

В уголовно-исполнительном праве Украины устоявшимся является мнение, что режим в исправительных и воспитательных колониях - это порядок исполнения и отбывания наказания. Такое понимание режима имеет свои исторические корни в советском гулаговском прошлом. Именно с $30-\mathrm{x}$ годов прошлого столетия по приказам и инструкциям НКВД режим для осужденных стал воплощением порядка исполнения и отбывания лишения свободы на основе их изоляции. С того времени и по сегодняшний день обеспечение изоляции осужденных рассматривается как основное требование режима. В советском исправительно-трудовом праве исходили из того, что изоляция является воплощением в себе ограничений прав и свобод присущих лишению свободы, то есть кары. Режим требует осуществления надзора за лишенными свободы путем круглосуточного и постоянного контроля в местах их проживания и работы. Средствами обеспечения режима являются обыски осужденных и помещений, в которых они находятся, осмотр территории колонии; применение к лишенным свободы мер физического воздействия, специальных средств и оружия. В отличие от такого понимания режима Европейские тюремные правила (ЕТП) различают заключение и лишение свободы и исходят из того, что заключение и лишение свободы являются наказанием уже сами по себе и поэтому режим для осужденных заключенных не должен увеличивать страдания причиненные заключением. Режим согласно ЕТП состоит из сбалансированной программы консультаций, заботы и помощи, направленной на облегчение реинтеграции заключенных в свободное общество после окончания их строка заключения. Режим предусматривает предоставление возможности получения образования, профессиональной подготовки, занятий спортом, организации отдыха и досуга. ЕТП далеки от того, чтобы рассматривать режим как порядок исполнения и отбывания наказания. Согласно ЕТП режим - это правила обращения с заключенными, именно так должен пониматься режим и в уголовно-исполнительном праве Украины. Актуальность исследования данного аспекта режима обусловлена необходимостью разработки предложений в отрасли уголовно-исполнительного права, которые соответствовали бы законодательству Европейского Союза, что предусмотрено Концепцией реформирования (развития) пенитенциарной системы Украины.

Ключевые слова: режим; порядок; исполнение наказаний; изоляция; правила обращения.

Постановка проблеми. Порівняльний аналіз норм кримінальновиконавчого законодавства України і міжнародних документів у сфері поводження із засудженими показує на принципово різне бачення призначення режиму у виправних колоніях і в'язницях. Подолання розбіжностей між вітчизняним законодавством i рекомендаціями Ради Європи стосовно поводження із ув'язненими $\epsilon$ проблемою, яку необхідно вирішити на шляху реформування Державної кримінально-виконавчої служби 
України, щоб привести умови тримання ув'язнених у слідчих ізоляторах та осіб, які перебувають у місцях позбавлення волі, до європейських стандартів, зокрема, в питанні організації режиму в установах виконання покарань. Ця наукова стаття виконана в рамках фундаментальної теми дослідження «Теоретичні питання удосконалення кримінальновиконавчого законодавства України та практики його застосування», за двома напрямами дослідження: 1) удосконалення кримінальновиконавчого законодавства України щодо гуманізації умов відбування покарання засудженими та забезпечення їх ресоціалізації та 2) соціальної адаптації та імплементації міжнародних стандартів поводження із засудженими та дотримання їх прав в законодавство України, які виконуються у Науководослідного інституту вивчення проблем злочинності імені академіка В. В. Сташиса НАПрН України.

Аналіз останніх досліджень та публікацій. Проблемі режиму у виправних і виховних колоніях приділяли увагу у своїх дослідженнях багато науковців, зокрема, це: М. О. Беляєв, С. А. Борсученко, А. І. Васильєв, М. Я. Гінзбург, Д. В. Горбань, М. Г. Козінець, П. П. Козлов, І. І. Лигалов, М. О. Ліненко, О. В. Масліхін, Ю. В. Нікітін, Й. С. Ной, Н. В. Ольховик, А. А. Павленко, А. В. Папуашвілі, С. В. Познишев, К. С. Раскін, К. Ш. Садреєв, В. І. Селіверстов, Л. О.Стрелков, М. О.Стручков, Б. Телефанко, $\begin{array}{ll}\text { В. М. Трубников, } & \text { Б. С. Утєвський, }\end{array}$ В. О.Уткін, В.А. Фефелов, С. Ю. Чекулаєв, О. Л. Шеметов, Є. Г. Шірвіндт, I. В. Шмаров, В. Є. Южанін та ін. Як правило, у всіх наукових працях указаних науковців звертається увага на те, що режим $є$ ключовим, центральним поняттям у кримінальновиконавчому праві, що поняття режиму ввійшло у радянське виправнотрудове законодавство одночасно 3 поняттям позбавлення волі. На протязі десятиріч режим знаходиться в центрі уваги як представників науки виправно-трудового (а тепер і кримінально-виконавчого) права, так і практичних працівників установ виконання покарань, які традиційно виходять 3 того, що саме у режимі знаходить своє втілення кара, притаманна позбавленню волі, що режим $є$ якісною характеристикою позбавлення волі, відображаючи якість і ступінь ізоляції. Таке бачення режиму не виходить за межі догм радянського виправно-трудового права, яке визнавало режим своєю центральною категорією, проголошуючи, що режим $\epsilon$ похідним від сутності і змісту покарання у виді позбавлення волі.

Постановка завдання. Метою даної статті $\epsilon$ доведення неприйнятності розуміння режиму, як порядку виконання і відбування покарань i аргументація необхідності приведення кримінально-виконавчого законодавства України у відповідність до міжнародних стандартів поводження з ув'язненими.

Виклад основного матеріалу. Основоположними нормативноправовими актами, які регулюють діяльність органів і установ виконання покарання, є насамперед Кримінально-виконавчий кодекс України, Закон України «Про державну кримінально-виконавчу службу України», Закон України «Про пробацію». При цьому законодавство України, її політика у сфері виконання покарань i пробації, як держави- 
учасниці Ради Європи, мають бути зорієнтовані на рекомендації Комітету Міністрів Ради Європи, а саме: на Європейські тюремні правила i Правила Ради Європи про пробацію. Рекомендації Комітету Міністрів Ради Європи є дороговказом, що визначає у якому напрямку має розвиватись кримінально-виконавче законодавство України. Зокрема, це стосується змісту режиму позбавлення волі.

За визначенням, яке дається у ст. 102 КВК України, режим у виправних і виховних колоніях - це встановлений законом та іншими нормативно-правовими актами порядок виконання і відбування покарання, який забезпечує ізоляцію засуджених; постійний нагляд за ними; виконання покладених на них обов'язків; реалізацію їхніх прав і законних інтересів; безпеку засуджених і персоналу; роздільне тримання різних категорій засуджених; різні умови тримання засуджених залежно від виду колонії; зміну умов тримання засуджених.

Визначення режиму через категорію «порядок» покликане відобразити найзагальніші, найбільш істотні його властивості. За визначенням, яке дається у Великому тлумачному словнику сучасної української мови, порядок - це стан, коли все робиться, виконується так, як слід, відповідно до певних вимог, правил; упорядкованість, лад; злагодженість, узгодженість у діях, організованість; додержання правил, норм поведінки де-небудь, дисципліна [1, c. 1074].

Основною вимогою режиму у виправних і виховних колоніях волі $\epsilon$ забезпечення ізоляції засуджених, оскільки ізоляція за ст. 63 Криміна- льного кодексу України $є$ змістом позбавлення волі. Ізоляція уособлює в собі обмеження прав і свобод притаманних позбавленню волі, тобто кару. Режим вимагає здійснювати нагляд за позбавленими волі шляхом цілодобового і постійного контролю в місцях їх проживання і праці. Засобами забезпечення режиму є обшуки засуджених та приміщень, в яких вони знаходяться, огляд території колонії; застосування до позбавлених волі заходів фізичного впливу, спеціальних засобів і зброї.

На відміну від такого розуміння режиму, відображеного у главі 16 КВК України, Європейські тюремні правила розрізняють ув'язнення i позбавлення волі і виходять 3 того, що ув'язнення і позбавлення волі $\epsilon$ покаранням вже самі по собі і тому режим для засуджених ув'язнених не повинен збільшувати страждання, заподіяні ув'язненням (правило 102.2) [2].

Режим за ЄТП складається зі збалансованої програми піклування, турботи і допомоги, спрямованої на полегшення реінтеграції ув'язнених у вільне суспільство після закінчення їхнього строку ув'язнення. Для цього стосовно кожного з ув'язнених складається план відбування покарання та стратегія підготовки до звільнення. ЄТП виходять з того, що потрібно заохочувати участь ув'язнених $\mathrm{y}$ складанні своїх індивідуальних планів відбування покарання. Такі плани повинні охоплювати: а) роботу; б) освіту; в) інші види діяльності; г) підготовку до звільнення. Індивідуальні плани відбування покарання ув'язнених, як складова частина режиму, мають регулярно переглядатися після всебічних консультацій між відповідним персоналом і ув'яз- 
неними, які повинні залучатися до цього процесу.

Режим для ув'язнених також може передбачати соціальну роботу, медичне обслуговування та психологічну допомогу (п.103.5).

Як невід'ємний елемент режиму для ув'язнених повинна передбачатися система відпусток з в'язниці (п.103.6).

Режим має бути розроблений таким чином, щоб ув'язнені у подальшому вели відповідальний спосіб життя без вчинення злочинів.

Режим повинен також дозволяти забезпечувати потреби добробуту ув'язнених (п. 25.3). Зокрема матеріально-побутове забезпечення повинно передбачати надання кожному ув'язненому індивідуального приміщення. Розміщення ув'язнених, i, зокрема, надання місць для сну, повинне проводитися 3 повагою до людської гідності та, по можливості, із забезпеченням можливості усамітнення (п. 18.1). Спільне поміщення ув'язнених в одну камеру має бути як виняток і лише за згодою ув'язнених. Ув'язнені мають забезпечуватись комплексним харчуванням 3 урахуванням їх віку, стану здоров'я, релігії, культури та характеру їхньої роботи (п. 22.1). Обслуговування ув'язнених має бути забезпечене таким чином, щоб кожний ув'язнений міг щоденно приймати душ або ванну, але принаймні два рази на тиждень (п. 19.4).

ЄТП до позитивних елементів режиму у в'язниці відносять зайнятість ув'язнених роботою (п. 26.1). Ув'язнені можуть обирати вид діяльності, в якій вони хотіли б брати участь, у межах наявних можливостей, 3 урахуванням відповідного професійного відбору та вимог порядку і дисципліни (п. 26.6).
Невід'ємною частиною режиму $\epsilon$ належним чином організовані заходи поліпшення фізичної форми ув'язнених і надання їм можливості виконувати фізичні вправи, а також можливості дозвілля і повноцінного відпочинку (п. 27.3).

Освіта ув'язнених повинна мати в рамках режиму не менший статус ніж праця (п. 28.4), або будь який інший вид зайнятості. Якщо запланований режим для засуджених ув'язнених передбачає їхню участь в освітніх або інших програмах у робочий час, то вони повинні отримувати за це грошову винагороду, як за роботу (п. 105.4). ЄТП виходять з того, що систематична програма освіти, яка включає професійне навчання та спрямована на підвищення загального рівня освіти ув'язнених, а також на поліпшення перспективи жити відповідально і не скоювати злочинів має бути ключовим елементом режиму для ув'язнених (п. 106.1).

За ЄТП режим, наскільки це можливо, мусить бути організований таким чином, щоб надавати ув'язненим можливість сповідувати свою релігію та віру, відвідувати служби або зібрання, які проводять представники таких релігій або вірувань, які отримали відповідний дозвіл; такі представники релігій або вірувань повинні мати можливість відвідувати ув'язнених і спілкуватися з ними в конфіденційній обстановці; ув'язненим треба дозволяти мати у себе книги та літературу, які стосуються їхньої релігії та вірувань (п. 29.2).

Таким чином, згідно з ЄТП режим $є$ програмою заходів поводження $з$ ув'язненими, спрямованими на надання їм допомоги у сприянні переходу від життя у в'язниці до законослухняного життя в суспільстві. 
Ще більш детально визначаються цілі і змістовне наповнення режиму у Рекомендації CM REC (2008) 11 Комітету міністрів Ради Європи державам-членам щодо $\epsilon_{\text {в- }}$ ропейських правил стосовно неповнолітніх правопорушників, засуджених до покарань і заходів кримінально-правового характеру [3]. Так, згідно 3 правилом 77 цієї Рекомендації цілями режиму $є$ навчання, особистий і соціальний розвиток, професійна освіта, виправлення і підготовка до звільнення. Режим включає: шкільну освіту, професійну підготовку, працю і трудотерапію, вивчення прав і обов'язків громадянина, навчання соціально корисним навичкам і умінням, поборення агресивності, лікування від наркоманії, індивідуальна і групова терапія, фізична підготовка і спорт, підвищення освітнього рівня, відшкодування боргів, програми відновлювального правосуддя і відшкодування шкоди, заняття творчістю в години дозвілля і хобі, заходи поза установою, відпустки різних видів, підготовка до звільнення і допомога у соціальній адаптації.

У зв'язку з викладеним постає питання, а чому така велика різниця між розумінням режиму у вітчизняному кримінально-виконавчому праві і у міжнародних документах. Треба сказати, що вироблене у міжнародних актах розуміння режиму має свою історію, яка сягає XIX сторіччя. Так, за повідомленням М.С. Таганцева на Стокгольмському тюремному конгресі 1878 року вже зверталась увага на необхідність регламентувати у законі самі начала тюремного режиму: порядок робіт, розмір заробітку i умови розпорядження ним арештанта, їжу, право побачень і листування, дисциплінарні проступки і відповідальність за них і т.і. [4, c. 251]. М. С. Таганцев вважав доцільною таку регламентацію, але законодавство царської Росії, не вживало термін «режим». Не набуло поширення це слово і у широкому вжитку. Так, у «Энциклопедическом словаре Брокгауза и Ефрона», який вийшов друком у 1890-1907 рр., і згадки немає про режим.

На початку XX сторіччя у науці тюрмознавства (пенітенціарній науці) були певні намагання охарактеризувати режим. Зокрема, цього питання торкнувся у 1923 році у роботі «Основы пенитенциарной науки» С. В. Познишев, який розглядав режим у широкому й вузькому значенні і вважав, що в широкому сенсі режим охоплює всю систему заходів, за допомогою яких пенітенціарні установи прагнуть до досягнення своїх цілей [5, с. 113-114].

Треба сказати, що у вітчизняному законодавстві вже була спроба наповнити зміст режиму в установах виконання покарань, виходячи із засад гуманізму, людинолюбства та 3 урахуванням точок зору на режим, які мали місце на міжнародних тюремних конгресах. Так, Поправнотрудовий кодекс УСРР 1925 року визначав у ст. 3 , що «режим в поправно-трудових установах повинен полягати в зміцненні в осіб, що вчинили злочини, таких рис удачі й звичок, які можуть їх стримати від дальших злочинів. За цього в поправно-трудових установах обов'язково належить уживати праці, не мати на оці завдавати фізичного болю, шкоди здоров'ю чи принижувати людську гідність в'язнів» [6, с. 42-43].

Стаття 4 «Заходів соціяльної оборони в поправно-трудових уста- 
новах уживається за поступовою (висхідною) системою. Відповідно до цієї системи в'язні підлягають різному i, як загальне правило, що-раз легшому режимові. Для цього їх поділяється по поправно-трудових установах різних типів і ділиться на розряди 3 наступним переводом 3 одного розряду до одного і з одної установи до одної, залежно від властивостей їх особи соціяльного стану, змісту судового вироку, причин, мотивів і приводів злочину, а також поведінки в поправно-трудовій установі й успіхів в роботі й на заняттях» [6, c. 43].

За статтею 47 ПТК УСРР «режим у поправно-трудових установах полягає у правильному сполученні принципів обов'язкової праці в'язнів і культурно освітньої роботи» [6, c. 50].

Стаття 48. «Для справжнього здійснення поправно-трудової політики, режим в поправно-трудових установах повинен бути позбавлений будь-яких ознак мордування, ні в якому разі не припускаючи натільної кари, кайданів, наручників, позбавлення їжі тощо» [6, с.50].

Стаття 49. «Режим в поправнотрудових установах будується за прогресивною системою з тим, щоб, залежно від характеру й властивостей в'язнів та часу їхнього перебування в тій чи іншій поправно-трудовій установі, вони могли в більшій чи меншій мірі виявляти свою самодіяльність та ініціативу» $[6$, с. 50].

Разом із тим, у ст. 51. Було визначено, що «всі в'язні повинні безвимовно коритись усім установленим для поправно-трудових установ правилам внутрішнього розпорядку й режиму, що їх видає НКВС, порозумівшись з НКЮ УСРР» [6, с. 50].
Така ж норма була і в ст. 48 Виправно-трудового кодексу РРФСР 1924 року. При цьому ст. 5 ВТК визначала, що всі місця ув'язнення РРФСР складають єдину систему виправно-трудових установ 3 різними видами режиму [7, с. 160]. Треба відмітити, що запропонований $\mathrm{y}$ ВТК РРФСР поділ радянських виправно-трудових установ за видами режиму існує по сьогоднішній день, оскільки в сучасній Російській Федерації і зараз функціонують виправні колонії загального, суворого i особливого режиму (ст. 74 КВК РФ) [8].

У подальшому положення ВТК, за якими режим, як поєднання праці і культурно освітньої роботи, мав би виключати мордування в'язнів, «ні в якому разі не припускаючи натільної кари, кайданів, наручників, позбавлення їжі тощо», з вимогою будувати режим за прогресивною системою, отримали оцінку як прояв ліберального ухилу, як спадок ліберальної пенітенціарії. 31929 року з першою п'ятирічкою в СРСР почався так званий реконструктивний період, якому була підпорядкована i виправнотрудова політика, при втіленні якої проголошувалась необхідність рішуче вилучити з ВТК все те, що $є$ відображенням буржуазної юридичної думки, категорично ліквідувати ліберальне збочення [9, с. 152], вивільнити кодекси від непотрібних і шкідливих буржуазно-правових понять, здійснити «чистку» кодексів від недоліків буржуазно-правової думки 3 метою найбільшого пристосування їх до директив партії і потреб даного етапу [6, с. 34-35]. Виправно-трудова політика цього періоду вже не відповідала тим гуманістичним засадам, на яких був створений ПТК УСРР 
1925 року і ВТК РСФРР 1924 року. Як видається, свою руку у «чистку» кодексів від недоліків буржуазноправової думки» приклав і один із основоположників радянського виправно-трудового права та провідник виправно-трудової політики Є. Г. Шірвіндт, який у 1922-1930 pр. очолював Головне управління місць ув'язнення РСФРР і одночасно 3 1926 року керував роботою над проєктом нового ВТК РСФРР. Є. Г. Шіврвіндт послідовно відстоював точку зору, що режим радянських виправно-трудових установ докорінно відрізняється від режиму у тюрмах капіталістичних країн. Режим, встановлений у радянських виправно-трудових установах, містить ряд принципово нових моментів, які настільки різко розривають зі специфічними тюремними атрибутами, органічно притаманних тюрмам у буржуазних країнах, що він надає цілком інші риси радянським виправно-трудовим установам i принципово видозмінює внутрішній зміст і характер порядку виконання вироку до позбавлення волі [10, c. 178].

10 вересня 1931 року в Державному інституті з вивчення злочинності, який створив і очолював Є.Г. Шірвіндт, була заслухана доповідь Б. С. Утєвського «Исправительно-трудовая политика реконструктивного периода» і головуючий на засіданні Нарком юстиції РСФРР М. В. Криленко наголосив на тому, що специфіка репресії полягає у режимі, що питання про диференціацію режиму необхідно вирішувати, виходячи із загальних завдань політики, а не з індивідуальних особливостей особи; режим необхідно будувати в залежності від класової належності.
Доповідач, який, як Нарком юстиції, був суб'єктом формування виправнотрудової політики реконструктивного періоду, пропонував виходити 3 того, вся сила вироку, все його політичне значення як акту класової боротьби проявляються в організації режиму, у більшому або меншому ступені ізоляції ув'язненого від зовнішнього світу, в характері праці тих чи інших класових категорій, у розпорядку дня [6, с. 126, 128]. Таким чином, один із очільників радянського режиму наголошував, що режим для ув'язнених має бути складовою частини політики. Політика ж радянської влади знаходила свій прояв у ізоляції населення від зовнішнього світу, в тому числі під страхом кримінальної репресії. Показово, що якщо за загальним правилом засуджені до позбавлення волі на строк до трьох років відбували покарання у виправно-трудових колоніях, то згідно з постановою ЦВК і РНК СРСР від 5 жовтня 1936 року незаконний виїзд за кордон карався ув'язненням у таборі від 1 до 3 років [7, с. 359]. Речник виправно-трудової політики наголошував, що ізоляція ув'язнених від зовнішнього світу має стати квінтесенцією режиму.

3 літературних джерел відомо, що у 30-і роки XX сторіччя ізоляцію ув'язнених від суспільства і організацію режиму здійснювала воєнізована охорона (ВОХР), завданнями якої у відповідності з «Временными наставлениями по службе военизированной охраны исправительнотрудовых лагерей НКВД СССР» 1939 року були: охорона ув'язнених, охорона готових споруд, складів, баз із матеріальними цінностями, конвоювання ув'язнених на виробництво, охорона їх під час виконання робіт, 
боротьба зі втечами, придушення групових виступів і непокори [11].

Таким чином, організація охорони ув'язнених особливо виділялась у числі основних функцій ГУЛАГу. Режим у виправно-трудових таборах, колоніях і в'язницях був покликаний забезпечити надійну ізоляцію, недопущення втеч ув'язнених і встановлення нелегальних зв'язків із зовнішнім світом [12].

Наказом НКВС СРСР від 2 серпня 1939 року була затверджена «Временная инструкция о режиме содержания заключенных в исправительно-трудовых лагерях НКВД СССР», а наказом НКВС СРСР від 4 липня 1940 року була затверджена «Временная инструкция о режиме содержания заключенных в исправительно-трудовых колониях НКВД СССР». Ці тимчасові інструкції визначали, що режим тримання ув'язнених як у виправно-трудових таборах, так i у виправно-трудових колоніях повинен забезпечити: а) надійну ізоляцію ув'язнених; б) організацію порядку тримання ув'язнених, щоб забезпечити найбільш ефективне використання їх праці [13].

Як вірно відмітив О. В. Дашин, саме ці Інструкції НКВС про режим тримання ув'язнених заклала системні основи регулювання режиму i охорони на наступні десятиріччя [14].

3 лютого1944 року у відповідності 3 наказом НКВС СРСР № 0458 від 28 грудня 1943 року у виправнотрудових таборах почала функціонувати внутрішня наглядова служба, яка отримала право безпосередньої організації режиму. В її функції входило посилення ізоляції ув'язнених, постійний нагляд за дотриманням ними правил режиму і внутрішнього розпорядку. Таким чином, 3 цього часу організацією режиму займалися два підрозділи - воєнізована охорона і внутрішня наглядова служба [15].

Про те, наскільки стало далеким від розуміння змісту режиму у чинному на той час Поправнотрудовому кодексі УСРР 1925 року свідчить наказ МЮ СРСР від 18 червня 1953 року «С объявлением структуры ГУЛАГа МЮ СССР и его периферийных органов», де в структурі управлінь передбачався відділи режиму i оперативної роботи, які мали своїм призначення забезпечення надійної ізоляції ув'язнених та порядку в структурних підрозділах ГУЛАГу [3,с.417-419]. Такий же підхід, щодо призначення режиму був продемонстрований і в подальшому. Так, згідно з п.4 Положення про виправно-трудові табори і колонії МВС СРСР 1954 року режим тримання ув'язнених повинен був забезпечувати їх ізоляцію, правильне праце використання, залучення у політиковиховну роботу і постійний нагляд i спостереження за ними. Пункт 15 Положення деталізував цю норму i вказував на те, що режим тримання ув'язнених повинен забезпечувати: а) суворе дотримання ув'язненими дисципліни, попередження втеч i інших злочинів; б) надійну охорону ув'язнених і ретельний нагляд за їх поведінкою; в) ізоляцію засуджених за контрреволюційні злочини, за інші тяжкі злочини, рецидивістів, а також осіб, які злісно порушували встановлений режим, від решти ув'язнених; г) роздільне тримання засуджених чоловіків і жінок і ізоляцію вперше засуджених від осіб засуджених неодноразово; д) створення ув'язненим відповідних житловопобутових умов, медичного й культурного обслуговування. Для засу- 
джених були встановлені три види режиму: загальний, суворий у виправно-трудових таборах і полегшений у виправно-трудових колоніях [6, c. 423-425].

Саме це Положення про табори і колонії започаткувало з 1954 року розподіл ув'язнених по установах за режимами.

15 грудня 1958 року наказом MBC СРСР № 990 було оголошено Положення про ВТК і тюрми МВС СРСР, згідно 3 яким у виправнотрудових колоніях встановлюються три види режиму: загальний, полегшений і суворий, а в тюрмах загальний і суворий [16].

Наука радянського виправнотрудового права грунтувалась на тогочасних нормативних приписах у сфері виконання покарань. Так, 3 урахуванням викладеного цілком зрозуміло, що у 1960 році М. О.Бєляєв визначав режим як встановлений і врегульований нормами радянського виправнотрудового права порядок життя i праці ув'язнених, що забезпечує їх ізоляцію, а також здійснення обмежень, зв'язаних з позбавленням волі, виконання ув'язненими їх обов'язків, гарантію здійснення належних їм прав і створення умов для їх виправлення і перевиховання [17, с. 178].

26 липня 1961 року Указом року Президії Верховної Ради УРСР було затверджено Положення про виправно-трудові колонії і тюрми МВС Української РСР, яким у відповідності зі ст. 25 КК УРСР 1960 року були передбачені виправно-трудові колонії чотирьох видів: загального, посиленого, суворого і особливого режимів, а також тюрми і виховно-трудові колонії [18]. Основні змістовні характеристики режиму полягали в тому, що режим у виправно-трудових колоніях і тюрмах повинен був забезпечувати: а) обов'язкову охорону i ізоляцію всіх ув'язнених і постійний нагляд за ними з тим, щоб виключити можливість вчинення ними нових злочинів; б) суворо роздільне розміщення ув'язнених в залежності від статі, характеру вчинених злочинів i особи; точне і неухильне виконання ув'язненими їх обов'язків і суворе дотримання дисципліни.

Режим покликаний був не тільки карати, але й виховувати у ув'язнених дисципліну, потребу $\mathrm{y}$ праці і свідоме дотримання правил соціалістичного співжиття.

У 1963 році М. О.Стручков виходив 3 того, що поняття режиму повинне означати цілком визначену юридичну дію - виконання покарання, а норми права, які передбачають режим позбавлення волі, встановлюють правила ізоляції засуджених, їх поведінку, а також умови ізоляції. Вказані правила звернені до засуджених i фіксують їх права i обов'язки. Обсяг правил режиму такий, що вони передбачають умови залучення засуджених до праці і політико-виховної роботи. Вказані правила і умови проведення роботи із засудженими створюють зміст режиму. Саме в режимі знаходить свій прояв кара притаманна покаранню. Встановлений у місцях ув'язнення режим, оскільки в ньому знаходить свій вираз кара, передбачає відомі обмеження побутового порядку. Ці обмеження повинні дати відчути засудженому, що він відбуває покарання. Тому з побуту рішуче усуваються будь-які зайвини [19, с. 96]. Таке бачення призначення режиму i по сьогоднішній день, тобто у XXI сторіччі, виправдовує в очах 
суб'єктів виконання покарань неналежні для сучасної цивілізації матеріально-побутові умови позбавлення волі.

Показані вище метаморфози 3 розумінням режиму від «правильного сполучення праці і культурно освітньої роботи » до характеристики його, як «втілення кари», «правил ізоляції», призвели до того, що у ст. 28 ВТК Української РСР 1970 року, який прийшов на зміну ПТК 1925 року, основними вимогами режиму в місцях позбавлення волі були визначені: обов'язкова ізоляція засуджених і постійний нагляд за ними, з тим, щоб виключалася можливість учинення нових злочинів та інших антигромадських вчинків; точне i неухильне виконання ними своїх обов'язків; різні умови тримання залежно від характеру та ступеня суспільної небезпечності вчиненого злочину, особи і поведінки засудженого.

ВТК УРСР, так само, як і ВТК інших республік СРСР не давав визначення поняття режиму. Цю прогалину у радянському виправнотрудовому праві намагались подолати на доктринальному рівні, характеризуючи його через категорію «порядок». Так, у підручнику «Исправительно-трудовое право», підготовленому кафедрою кримінального права Ленінградського державного університету режим відбування покарання визначався як встановлений нормами радянського виправнотрудового права порядок тримання у виправно-трудових установах осіб, засуджених до позбавлення волі, який забезпечується діяльністю адміністрації виправно-трудових установ 3 виконання покарання у відповідності 3 його цілями [20, с. 220]
Автори підручника виходили з того, що режим регламентує життя засуджених у місцях позбавлення волі на протязі всього строку відбування покарання, встановлює межі дозволеного в поведінці засуджених і таким чином визначає їх правове становище; режим у виправно-трудових установах завжди містить каральні елементи, інакше він не буде режимом виконання покарання; каральна сторона режиму знаходить свій вираз у право обмеженнях, яким підлягає засуджений: в ізоляції, обмеженнях у побаченнях, користуванні грошима і т. ін. [20, с. 222-223].

М. О. Стручков у своїх роботах, які вийшли друком у 60-80-і роки, послідовно відстоював свою точку зору, висловлену ще у 1963 році, що режим є виразом сутності покарання, що режим виконує каральну функцію, яка знаходить свій вираз в ізоляції засуджених до позбавлення волі, в різноманітних право обмеженнях, які відносяться до матеріальних і духовних благ, застосуванні надзвичайних заходів безпеки, що саме режим як комплекс право обмежень створює засудженому обтяження, позбавлення, спричиняє страждання [21, с. 48-59].

\section{Характеризуючи}

режим, М. О. Стручков згадав, що в 20-30-і роки С. В. Познишев і Б. С. Утєвський вважали, що режим у широкому розумінні - це система заходів, які використовуються для досягнення цілей, що стоять перед виправнотрудовими установами, а у вузькому - це сукупність правил поведінки засудженого [22, с. 93-94]. На наш погляд, те, що у минулому сторіччі характеризували режим у широкому і вузькому значенні $€$ не що інше як режим виконання покарання (систе- 
ма заходів) і режим відбування покарання (сукупність правил поведінки). При цьому М. О. Стручков виходив $з$ того, що коли брати за основу загальноприйнятне і зрозуміле кожному значення слова «режим» (від франц. regime), то прийдеться визнати ним порядок, спосіб, уклад життя засудженого [22, с. 94]. Таке тлумачення «regime» в наступні десятиріччя повторювалось у науці виправнотрудового права, а потім і в кримінально-виконавчому праві. На це треба сказати, що звертання до словників дає дещо інше розуміння режиму, ніж у тому значенні цього слова, яке, як вважав М. О. Стручков $є$ «загальноприйнятним i зрозумілим». За життя М. О. Стручкова визнання широкого кола читачів набув «Словарь русского языка» С. І. Ожегова, однак у цьому словнику режим не тлумачиться як порядок, а розуміється як: 1) розпорядок справ, дій; 2) умови діяльності, роботи, існування чогонебудь; 3) державний лад [23, с. 696]. Так, словник іноземних слів виходить 3 того, що режим (фp. regime) 1) державний устрій, спосіб правління; 2) точно встановлений розпорядок життя: праці, відпочинку, сну, харчування і т. i.; 3) система правил, заходів, необхідних для тієї чи іншої мети; 4) умови діяльності, роботи, існування чого-небудь. [24, с. 433]. Так само розуміється режим і за Великим тлумачним словником сучасної української мови: «режим. 1. Державний лад, спосіб правління. 2. Точно встановлений розпорядок життя, праці, відпочинку і т. ін. Постільний режим. 3. Система заходів, правил, запроваджених для досягнення певної мети. 4. Певні умови, необхідні для забезпечення роботи, функціонування, існування чого- небудь. 5. Сукупність параметрів, які характеризують функціонування об'єкта. 6. Стан системи, що визначається множиною різних процесів [1, c. 1208]. Отже, жоден із варіантів тлумачення поняття «режим» не дає підстав розуміти його як «порядок», а те, що поряд 3 «порядком» М. О.Стручков застосував термін «уклад життя засудженого» нічого нового не додало до його розуміння режиму, тому що уклад - це порядок, який був установлений або склався (у житті, побуті, родині, установі) [1, c. 1500].

Як уже було показано вище, розуміння режиму позбавлення волі як порядку, як уособлення кари, як вираз змісту і сенсу покарання, який забезпечується ізоляцією та наглядом, було започатковано у радянському виправно-трудовому праві на підставі наказів НКВС часів існування ГУЛАГу, але відповідь про етимологію терміну «режим», його споріднені зв'язки з «порядком», «карою» можна, як видається, знайти у «Толковом словаре живого великорусского языка» Володимира Даля, де режим визначається як встановлений образ, порядок життя, відносно розподілу часу, відносно їжі і т. ін. [25, c. 1670]. При цьому В. Даль, щоб розтлумачити зміст режиму посилається на «прижим», яке означає гноблення, утиски, давлення, надавлювання $[25$, с. 1078$]$. Саме у розумінні режиму як прижиму, тобто як засобу гноблення засуджених, утисків, позбавлення прав і свобод почали застосовувати у радянських виправнотрудових таборах, виправнотрудових колоніях і в'язницях.

Варто звернути увагу на ще один історичний аспект витоків розуміння режиму як уособлення кри- 
мінальної репресії через категорію «порядок». Сторіччя назад «Руководящие начала по уголовному праву РСФСР» право визначали як систему (порядок) суспільних відносин, яка відповідала інтересам панівного класу і охоронялась організованою його силою. Під злочином розумілось порушення порядку суспільних відносин, які охоронялись кримінальним правом, а покарання - це ті примусові заходи, якими влада забезпечує даний порядок суспільних відносин $[7$, c. 58]. Отже право, кримінальне право, злочин і покарання визначалися через порядок. Видається, саме такий підхід у подальші десятиріччя зумовив те, що науковці радянського виправно-трудового права віддали данину історичній пам'яті і визначили режим як порядок виконання i відбування покарання.

У повній відповідності з цими радянськими уявленнями про зміст режиму, як уособлення кари, його основні вимоги, елементи, засоби його забезпечення знаходиться і визначення режиму, як порядку виконання і відбування покарання, яке міститься у ч. 1 ст. 102 КВК України. Таке розуміння режиму за всіма своїми параметрами не відповідає уявленню про призначення режиму, яке дається Європейськими тюремними правилами, і підлягає перегляду.

На наш погляд, режим у колоніях не повинен визначатися як порядок виконання і відбування покарання, а повинен розумітися як система заходів, що здійснюються $\mathrm{y}$ кримінально-виконавчих установах, спрямованих на полегшення реінтеграції засуджених у суспільство після відбуття покарання і сукупність правил поведінки засуджених під час знаходження у кримінальновиконавчій установі. Це має бути не режим виконання і відбування покарання, а режим поводження із засудженими, що відповідатиме Європейським тюремним правилам і Miнімальним стандартним правилам ООН стосовно поводження 3 в'язнями (Правилам Нельсона Мандели) i під цим кутом зору провідного значення набуває норма, закріплена у ч. 2 ст. 102 КВК України: «режим у колоніях має зводити до мінімуму різницю між умовами життя в колонії і на свободі, що повинно сприяти підвищенню відповідальності засуджених за свою поведінку і усвідомленню людської гідності».

Як видається, це положення необхідно розвинути i наповнити таким змістом режиму, такими його елементами, які рекомендовані Європейськими тюремними правилами, тобто режим має бути не порядком виконання і відбування покарання, а програмою соціальної допомоги засудженим, спрямованою на полегшення їх реінтеграції у суспільство після звільнення. У практичній площині це означає, що, якщо слідувати рекомендаціям ЄТП, то організацію і здійснення режиму на себе має перебрати насамперед персонал, функцією якого на сьогодні є соціально-виховна та психологічна робота із засудженими. Що ж стосується забезпечення ізоляції, здійснення нагляду, контролю, підтримання дисципліни, запобігання правопорушенням, то все це має розглядатися як компоненти фізичної, динамічної і процедурної безпеки, поєднання яких і створює мінімальний, середній і максимальний рівень безпеки в'язниці. 


\section{Список використаних джерел}

1. Великий тлумачний словник сучасної української мови (з дод. і допов.) / Уклад. і голов. ред. В.Т. Бусел. Київ, Ірпінь : ВТФ «Перун», 2005. 1728 с.

2. Європейські в'язничні правила. URL.: https://zakon.rada.gov.ua/ laws/show/994_032 (дата звернення: 10.10.2019).

3. Рекомендація CM REC (2008) 11 Комітету міністрів Ради Європи державамчленам щодо Європейських правил стосовно неповнолітніх правопорушників, засуджених до покарань i заходів кримінально-правового характеру. URL: https://rm.coe.int/16806ccb95 (дата звернення: 10.10.2019).

4. Таганцев Н. С. Русское уголовное право В 2 частях. Часть 2. Москва : Изд-во Юрайт, 2019. 446 с.

5. Познышев С. В. Основы пенитенциарной науки. Москва : Мосполиграф, 1923. $342 \mathrm{c}$.

6. Хрестоматія з історії пенітенціарної системи України. Упор. І. І. Резнік. Донецьк: ТОВ «Східний видавничий дім», 2011.510 с.

7. Сборник материалов по истории социалистического уголовного законодательства (1917-1937 гг.). Москва : Юридическое издательство НКЮ, СССР, 1938. 372 с.

8. Уголовно-исполнительный кодекс Российской Федерации от 08.01.1997 N 1-Ф3 (ред. от 26.07.2019). URL: http://www.consultant.ru/document/cons_doc_LAW_ 12940/38b47826d652ca12c249d03ffa5cf5ca424ef213/ (дата звернення: 10.10.2019).

9. Траскевич Ф. Исправительно-трудовая политика. Еженедельник советской юстиции. 20 февраля 1929 г. № 7. C. 152-155. URL: https://www.prlib.ru/item/332176 (дата звернення: 10.10.2019).

10. Ширвиндт Е. Г., Утевский Б. С. Советское исправительно-трудовое право. Москва : Госюриздат, 1957. 157 с.

11. Охрана заключенных в исправительно-трудовых лагерях 30-50-е годы XX века. URL: https://articlekz.com/article/5187 (дата звернення: 10.10.2019).

12. Организация охраны исправительно-трудовых учреждений Советского государства. URL: https://studbooks.net/1088017/pravo/organizatsiya_ohrany_ispravitelno _trudovyh_uchrezhdeniy_sovetskogo_gosudarstva (дата звернення: 10.10.2019).

13. Временная инструкция о режиме содержания заключенных в исправительно-трудовых лагерях НКВД CCCP. URL: https://www.alexanderyakovlev.org/ fond/issues-doc/1010319 (дата звернення: 10.10.2019).

14. Дашин А. В. Уголовно-правовые особенности содержания заключенных и деятельность администрации по предупреждению массовых неповиновений в исправительно-трудовых лагерях CCCP URL: https://cyberleninka.ru/article/v/ugolovnopravovye-osobennosti-soderzhaniya-zaklyuchennyh-i-deyatelnost-administratsii-popreduprezhdeniyu-massovyh-nepovinoveniy-v (дата звернення: 10.10.2019).

15. Косынтаев К. Б., Дильманов С. Д. Охрана заключенных в исправительнотрудовых лагерях 30-50-е годы XX века. URL: https://articlekz.com/article/5187 (дата звернення: 10.11.2019).

16. Приказ МВД СССР № 990 с объявлением «Положения об ИТК и тюрьмах МВД СССР» 15.12.1958. URL: https://www.alexanderyakovlev.org/fond/issuesdoc/1009165 (дата звернення: 01.10.2019).

17. Советское исправительно-трудовое право. Учебное пособие. Под общ. ред. Б. С. Утевского. Москва : Госюриздат, 1960. 278 с.

18. Главные исторические события развития пенитенциарной службы Украины. URL: https://www.kvs.gov.ua/peniten/control/main/ru/publish/article/634200 (дата звернення: 10.10.2019). 
19. Стручков Н.А. Советское исправительно-трудовое право. Общая часть. Курс лекций. Москва : НИРИО ВШ МООП РСФСР, 1963. 224 с.

20. Исправительно-трудовое право / Отв. ред. Н. А. Беляев, М. И. Фёдоров. Москва : Юридическая литература, 1971. 416 с.

21. Стручков Н.А. Курс исправительно-трудового права: Проблемы Особенной части. Москва : Юрид. лит., 1985. 256 с.

22. Наташев А. Е. Стручков Н. А. Основы теории исправительно-трудового права. Москва : Юрид. лит., 1967. 190 с.

23. Ожегов С. И., Шведова Н. Ю. Толковый словарь русского языка. Москва : Азъ Ltd, $1992.960 \mathrm{c.}$

24. Словарь иностранных слов. Москва : Рус яз., 1988. 624 с.

25. Даль В. И. Толковый словарь живого великорусского языка: В 4 т. Т. 3: Л-Р / Под ред И.А. Бодуэна де Куртенэ. Москва : ТЕРРА-Книжный клуб, 1998. 1782 с.

\section{References}

Busel, V.T. (red.). (2005). Velikij tlumachnij slovnik suchasnoyi ukrayinskoyi movi (z dod. i dopov.). Kiyiv, Irpin: VTF «Perun» [in Ukrainian].

Tagancev, N. S. (2019). Russkoe ugolovnoe pravo. Chast 2. Moskva : Izd-vo Yurajt [in Russian].

Hrestomatiya z istoriyi penitenciarnoyi sistemi Ukrayini. (2011). Upor. I. I. Reznik. Doneck: TOV «Shidnij vidavnichij dim» [in Ukrainian].

Shirvindt, E. G., Utevskij, B. S. (1957). Sovetskoe ispravitelno-trudovoe pravo. Moskva: Gosyurizdat [in Russian].

Sovetskoe ispravitelno-trudovoe pravo. (1960). Pod obsh. red. B. S. Utevskogo. Moskva: Gosyurizdat [in Russian].

Struchkov, N.A. (1963). Sovetskoe ispravitelno-trudovoe pravo. Obshaya chast. Moskva: NIRIO VSh MOOP RSFSR [in Russian].

Belyaev, N. A., Fyodorov, M. I. (red.). (1971). Ispravitelno-trudovoe pravo. Moskva: Yuridicheskaya literatura [in Russian].

Struchkov, N. A. (1985). Kurs ispravitelno-trudovogo prava: Problemy Osobennoj chasti. Moskva: Yurid. lit. [in Russian].

Natashev, A. E. Struchkov, N. A. (1967). Osnovy teorii ispravitelno-trudovogo prava. Moskva: Yurid. lit. [in Russian].

Ozhegov, S. I., Shvedova, N. Yu. (1992). Tolkovyj slovar russkogo yazyka. Moskva: Az Ltd [in Russian].

Slovar inostrannyh slov. (1988). Moskva: Rus yaz. [in Russian].

Dal, V. I. (1998). Tolkovyj slovar zhivogo velikorusskogo yazyka: V 4 t. T. 3: L-R / Pod red I. A. Boduena de Kurtene. Moskva: TERRA-Knizhnyj klub [in Russian].

A. Stepaniyk, Doctor of Law, Professor, Academician Stashis Scientific Research Institute for the Study of Crime Problems of the National Academy of Law Sciences of Ukraine

e-mail: astepaniyk@ukr.net; ORCID: 0000-0002-0877-6319

\section{The regime is not an "order of execution and serving of punishment" but the program of social assistance in dealing with prisoners}

In Ukrainian criminal-executive right, it is believed that the regime in correctional colonies - is the procedure of execution and serving the punishment. 
Such understanding of the regime has its historical roots in the Soviet Gulahivske past. Since the 30-ies of the last century in the orders and instructions of the NKVD regime for the prisoners was the embodiment of order on the basis of their isolation. Since then to the present day guaranteeing the isolation of prisoners is considered as a basic requirement of the regime. The Soviet correctional-labor law proceeded out the fact that isolation personifies restriction of rights and freedoms that is inherent for imprisonment, otherwise the penalty. The regime requires supervision over the deprived of freedom during days and nights and constant control in places of their residence and work. The methods of maintening the regime are searches of convicts and premises in which they are located, inspection of the territory of colony; applying to the deprived of will measures of physical influence, special means and weapons. In spite of such understanding of the regime, the European Prison Rules (EPR) distinguishes between imprisonment and deprivation of liberty and proceeds from the fact that imprisonment and depriving of will are punishments by themselves and that's why the regime for sentenced prisoners should not increase the suffering caused by imprisonment. The regime by the EPR consists of a balanced program of consultations, patronize, care and assistance aimed for facilitating the reintegration of prisoners in the free society after the expiration of their imprisonment. The regime envisages the possibility of obtaining education, training, sports, recreation. The EPR is far from being considered as the order of execution and serving of punishment. According to the EPR regime is the rules of treatment of prisoners, this is how the regime and the criminal-executive law of Ukraine should be interpreted. Actuality of the study of this aspect of the regime is caused by the necessity of developing proposals in the field of criminal executive law that would be corresponded to the legislation of the European Union, which foresees the concept of reforming (development) of the penitentiary system of Ukraine.

Keywords: regime; order; execution of sentences; isolation; rules of treatment. 